NBER WORKING PAPER SERIES

\title{
WILL UNIONISM PROSPER IN CYBER-SPACE? THE PROMISE OF THE INTERNET FOR EMPLOYEE ORGANIZATION
}

\author{
Wayne J. Diamond \\ Richard B. Freeman \\ Working Paper 8483 \\ http://www.nber.org/papers/w8483
NATIONAL BUREAU OF ECONOMIC RESEARCH
1050 Massachusetts Avenue
Cambridge, MA 02138
September 2001

This paper has benefited from the November, LSE Centre for Economic Performance Internet and Economy conference and the May 21-22 Trades Union Congress, LSE Centre for Economic Performance and Harvard Trade Union Program sponsored “Unions and the Internet” conference, and from participation on the TUC's Task Group on Promoting Trade Unionism. Elaine Bernard and Nigel Stanley have provided valuable commentary. The views expressed herein are those of the authors and not necessarily those of the National Bureau of Economic Research.

(C) 2001 by Wayne J. Diamond and Richard B. Freeman. All rights reserved. Short sections of text, not to exceed two paragraphs, may be quoted without explicit permission provided that full credit, including (C) notice, is given to the source. 
Will Unionism Prosper in Cyber-Space?

The Promise of the Internet for Employee Organization

Wayne J. Diamond and Richard B. Freeman

NBER Working Paper No. 8483

September 2001

\begin{abstract}
$\underline{\text { ABSTRACT }}$
This paper argues that the low cost of information, communication, and interaction on the Web offers trade unions opportunities to improve services and attract members and thus reinvent themselves for the $21^{\text {st }}$ Century. Analyzing current use of the Internet by unions in the United Kingdom and United States, we develop five hypothesis about the impact of the Internet on unions. 1) the Customized Services hypothesis that unions will individualize services; 2) the Cyber-organizing hypothesis that the Web will ease organization and produce virtual minority unions at many non-union firms; 3 ) the Cyber-democracy hypothesis that the Web will enhance democracy in unions; 4) the Cyber-dispute hypothesis that the Web will become an important space for industrial disputes; and 5) the New Internationalism hypothesis that the Web will strengthen the international labor community. If unions fail to exploit the opportunities on the Web to gain members, we expect other organizations, Internet recruitment sites, specialized advice centers, and the like, to fill the e-union niche.
\end{abstract}

Wayne J. Diamond

Centre for Economic Performance

London School of Economics

w.j.diamond@1se.ac.uk
Richard B. Freeman

Harvard University, NBER,

Centre for Economic Performance, London School of Economics a.freeman@1se.ac.uk 
The Internet is the $21^{\text {st }}$ Century's mode of mass communication. ${ }^{1}$ In 2001 over $70 \%$ of Americans and Scandinavians, 50\% of the British, and over a third of persons in most other advanced OECD countries used the Internet. The logistic growth curve for internet usage in the US parallels that for television in the 1950s (Thierer, 2000, chart 3), making the Internet one of most rapidly adopted innovations ever.

Some analysts believe that the Internet will render superfluous intermediate organizations like unions since the Internet can link individuals directly to firms and governments (Grossman, Corrado and Firestone; Agromonte; Castells). According to this view, "(T)he big losers (from the Web) ... are the traditional institutions that have served as the main intermediaries between government and its citizens - the political parties, labor unions, civic associations ... (Grossman, p. 16"). ${ }^{2}$ By contrast, some analysts of unions and technology (Shostak, Lee, Darlington) argue the opposite - that the Internet will be a transforming technology that will reinvigorate trade unionism.

What is the impact of the Internet on employee organization and representation? How have unions responded to the new technology? Can the Internet strengthen labor in the US and UK? Will unionism prosper or wither in Cyberspace?

${ }^{1}$ Internet refers to the infrastructure of interconnected computer networks. The World Wide Web or Web refers to one of the protocols that transfers information on the Internet. But these terms are increasingly used interchangeably and that is what we do in this essay.

${ }^{2}$ Bimber offers a valuable critique of this view and a more nuanced analysis of how the Internet will affect interest groups. 
Since the Internet is a recent phenomena, answers to these questions must be based on logical extrapolations of Internet capabilities and interpretation of emerging patterns of Web use rather than detailed econometric or historical analysis. As far as possible, we ground our answers in data: surveys of Web use by workers; a compendium of the Web presence of unions; examples of leading edge union Web activities; and a review of worker-oriented Web-based services from nonunion organizations. We present our conclusions in the form of hypotheses about how the Internet affects unions with examples to illustrate those effects.

Our principal conclusion is that the Internet offers unions great opportunities to improve services and attract members because it bridges the gap between an increasingly heterogeneous and individualistic work force and the collective activity and solidarity that lies at the heart of trade unionism. If, because of organizational rigidities, unions fail to exploit the opportunities of the Web, we expect other organizations - Internet recruitment firms, occupational associations, ethnic or gender-based groups - to do so.

\section{Worker and union members use of the Web}

To begin, it is important to recognize that union members and other workers are increasingly on line in the UK and US.

The best evidence on union members' use of the Web in the UK comes from the June/July 2001 British Workers Representation and Participation Survey, which contained information on 
Internet usage by union status (Diamond and Freeman, 2001). Exhibit 1 shows that union members are slightly more likely to have accessed the Internet in the previous month than nonunion members, in part, it seems, because they have greater access at work. Of those with access, unionists have been on the Web for roughly the same time as non-unionists, and are as likely to have access at home as non-unionists. Multi-variate regressions summarized in Appendix A, show that controlling for age (union workers are older than non-union workers), gender (unionists are disproportionately male), education (unionists are a bit better educated), wages (union workers earn a modest union premium) and sector of work (unionists are more likely to be in the public sector), strengthens this conclusion. In the UK 2001 union workers were as likely to use the Internet as nonunion workers with similar demographic characteristics, as well as overall.

The data on Web usage in Exhibit 2 shows that many workers use the Internet to search for information about jobs, but that union workers do much less job search on the Web than nonunion workers. This reflects the fact that union workers are older and more likely to hold permanent jobs. The exhibit also shows that union workers make less use of discussions/on-line chats, accessing bulletin boards, or seeking information on financial or legal rights - perhaps because union membership offers them a separate channel of information and discussion - but the differences here are modest.

The best evidence on union members' access to the Web in the US comes from the August 2000 CPS Internet and Computer Use supplement, a survey which contained questions about household members' use of the Internet, and data on union membership. Exhibit 3 summarizes 
the information on this survey about union members' use of the Internet. In the US as in the UK union members are highly wired and as likely to access the Web as non-members. In addition, they use it for similar purposes. ${ }^{3}$

\section{Unions on the Web}

Although unions were slow adaptors to the Web, thousand of unions and union activist groups around the world have gone on-line. In the early 1990s many US unions built web sites. In the UK UNISON established the first union website in March 1995. In the late 1990s many union federations and locals developed their own sites (IRS Employment Trends, 638).

Tracking union and union web sites on the Web is not easy, because there is no union domain name which would facilitate identifying union web sites. ${ }^{4}$ To estimate the number of union sites, we combined sites listed at the Cyberpicketline (www.cyberpicketline.org.uk) with those in various union website directories, and estimate that as of April 2001 there were over 2,700 union sites. $^{5}$ Since we undoubtedly missed many locals and dissident sites, and many sites in countries

${ }^{3}$ www.lo.se/english/news/internet.htm. "The use of Internet is steadily increasing" contains data on Swedish unionists' use and access to the Web. In $200032 \%$ of LO (blue collar) union members, $55 \%$ of TCO (white collar) members, and $66 \%$ of SACO (academic) union members used the Internet in the past twelve months. A larger proportion of all groups, including blue-collar LO members have access to the Web

${ }^{4}$ In November 2000, the Internet Corporation for Assigned Names and Numbers, the private group that determines domain names, rejected the request of the International Confederation of Free Trade Unions IFCTU to create a dot-union name, despite a campaign from union groups and the recommendation of its own investigative committee (Lee, 2000)

${ }^{5}$ The main source of our estimate is the Cyberpicketline web site supplemented by URLs 
that the directories do not cover well, this is a substantial underestimate. But it does give a reasonable count of union sites accessible by major search engines and union website directories. Exhibit 4 shows the ecology of the union web world as of April 2001. In terms of absolute numbers, the English-speaking countries make up the largest proportion of union web sites $57 \%$ of all the listed sites (this may reflect our failure to search in non-English languages for local union sites) - with the US accounting for $26 \%$ of the sites and the UK $14 \%$ of the sites. There are sixty international trade union secretariat sites on line: the International Confederation of Free Trade Unions (ICFTU), the Union Network International (UNI), the International Transport Workers Federation (ITF), etc, each linked to their associated national unions around the world. Nearly ninety percent of the union sites are from OECD countries, which also dominate the distribution of Internet hosts, more broadly. As the Internet use expands into less advanced countries, union use will expand concomitantly save possibly in China, which outlaws independent trade unions.

Union web sites vary immensely in what they offer. Some are simple bulletin boards or posters, the equivalent of a yellow page style advertisement. Others are sophisticated sites designed to make maximum use of the Web technology. In September 2000 the AFL-CIO used its portal www.workingfamilies.com to develop a virtual labor day for members to replace what had become a day of dwindling marches with ancient banners in a few cities. In 2001, the Federation held the second Online Labor Day Festival ( www.aflcio.org/laborday). Another innovative use

from www.xpdnc.com/links and elsewhere. The number of union web sites has increased greatly since September 1998, when Steve Davies estimated that there were 1,700 union web sites. (www.cf.ac.uk/ccin/union/eng.htm) 
of the Web as source of information is found in the Hotel and Restaurant Employees Union www.eyesonsodexho.com site. This site provides data on the Sodexho-Marriot corporations record in food safety and labor relations in ways that will make it hard to sympathize with the firm in any organizing drive.

The question is not whether the Internet will become part of the normal union activity. It has already done so. The question is whether unions will be able to use the Internet to build a modern growing movement.

\section{The opportunity of Cyberspace}

The Internet is an inexpensive cornucopia of information. As of August 11, 2001, there were perhaps 7 trillion web pages. ${ }^{6}$ Non-negligible proportions are updated regularly. As a result, millions of people rely on the Web as their first source of information on almost everything. The ability to post information cheaply on the Web creates an opportunity for unions to present labor's case directly to the public without expensive advertising or reliance on the media. It also creates an opportunity to influence journalists, who increasingly use the Web to research stories. An example of imaginative use of the Web to disseminate information is the AFL-CIO's www.aflcio.org/paywatch. This site gives information about CEO pay at firms in a manner that

\footnotetext{
${ }^{6} \mathrm{We}$ base this statistic on two numbers. The total number of pages that Google accesses 1.39 trillion as of August 11, 2001 But Google covers perhaps 1/5 of the web. Steve Lawrence and C. Lee Giles "Accessibility of Information on the Web", Nature, 400, 107-109 (1999) show that even the most comprehensive search agent covers no more than a fifth. They estimate that there were 800 million pages as of February 1999.
} 
highlights the huge and rising income inequality between workers and CEOs. The site received 11 million hits in 2000. In April 2001, the site added email links to company directors to encourage workers and shareholders to protest what it viewed as egregious CEO pay. On the other side, the massive flow of information on the Internet creates a role for unions as interlocutors or guides. Most union members are only marginally or intermittently involved in public issues and are unlikely go on-line on matters beyond their immediate concerns without some nudging. It is up to unions to convince members that an issue is important and to direct them to the relevant web sites. In the market for information, as in other markets, there is a demand as well as a supply side, and it is the job of intermediate organizations to direct demand in directions that fit their goals. ${ }^{7}$

The Internet is also an inexpensive medium for communication. E-mails can be sent at zero marginal cost to all members of an organization as well as from one person to another; and members can send e-mail protests to the government or to the union. Many unions use e-mails to contact members and to organize new members. The MSF union in the UK has an e-list that its representatives use to communicate information. The UK's Association of University Teachers used e-mail in its campaign to organize fixed term academic staff. The US's American Federation of Teachers used e-mail to reach out to a large number of part-time instructors, who intermittently visited the college campus, in its drive at Polomar College in San Diego. ${ }^{8}$

${ }^{7}$ As Catherine Needham has noted, " the Internet is a difficult medium thorough which to reach the unmobilised and uninterested. Visitors to a website have to make an explicit choice to be there." (Needham, 2001, p 31).

${ }^{8}$ http://www.gigalaw.com/articles/2001/towns-2001-06-p6.html. Accessed August 12, 
Similarly, unions can exploit the communication power of the Web to ask members or activists to bombard authorities with email protests on particular issues. The AFL-CIO sends e-mail messages to protest some action or other in the US regularly.

The Internet is also an inexpensive way for individuals to interact and participate in decisions or meetings that they would otherwise have missed ${ }^{9}$ Chat rooms, discussion forum, and list servers create virtual communities that can develop new thinking on issues as well as share information outside of official settings. Unions can conduct inexpensive plebiscites and canvass members about alternative ways to solve problems. Perhaps most importantly, activists can sidestep union hierarchies, devising plans and sharing information on the Web without worrying about protocol. And individuals can stir up others. When IBM changed its pension system in 1998 in ways that greatly harmed some workers, the workers went to on-line chat rooms to make their case against the company.

From an economics perspective, it is the low cost of information, communication, and interaction on the Web that promises to change how unions operate in the next decade. The reduced cost of providing some services and of interacting with members and the outside world in particular ways will lead unions to expand in those areas, potentially leading to a new "e-union" organization. We encapsulate the various ways we expect the Internet to change unionism in the form of five testable hypotheses relating to: 1) the services unions provide; 2) modes of organizing; 3) union democracy; 4) labor disputes; and 5) international union activity.

${ }^{9}$ Telephones are also interactive, but (small conference calls notwithstanding) largely on a one- to-one basis rather than on a person-to-group basis. 


\section{H1. The Customized Services hypothesis that unions will individualize services to members}

"The membership of trade unions will increasingly demand the levels of services which can only be provided by the ... e-union ... Our members will find that, in dealing with other organisations, they are given increasingly speedy and personalised service on a 24 our 7 day a week basis. They will expect no less from their trade union." Roger Darlington, Communication Workers Union (UK).

By lowering the cost of providing various services to members, the Internet will allow unions to meet the demand for new services that Darlington has identified. The easiest way for unions to improve services to members via the Internet is to connect local representatives and activists to national or international expertise through weekly on-line meetings; chat rooms; educational emails. In this vein, the TUC has developed a weekly e-bulletin, Risks aimed to keep safety reps and others informed about health and safety news (www.tuc.org.uk/risks). The UK building workers union UCATT has an online forum for its safety representatives. By giving union representatives greater information to do their jobs, the central union bodies will improve the ability of branches and locals to service members.

The second way in which unions will use the Internet to deliver services to members is through artificial intelligence expert systems that provide advice on labor laws, work-related issues and problems. These programs will answer workers' questions and provide isolated workplaces with expert advice. Members will initiate an interactive session with the AI expert program "Sam Gompers" (or "Ernest Bevin", or whoever) that embody information about labor issues much as 
existing medical, legal, and other AI experts do in other fields. The union database will eventually include the particulars of the member, so that the AI expert or union representative can customize the advice. Given a membership data base with e-mail addresses and personal characteristics, moreover, the union will be able to take a more proactive stance in servicing members, providing them with information about training, job prospects, schooling for the children, etc, in addition to responding to workplace-based complaints. If the member has a medical problem, and some medical advance occurs that can improve the person's life, the eunion will transmit the information instantly.

In the UK, in 1998 UNISON established UNISONDIRECT, a helpline call service that provides advice to union members 18 hours a day and Saturday. While the UNISON system uses a 17seat call centre rather than computer linkages to respond to members' problems, it makes extensive use of IT to deliver its services (Whitfield, 2001). The call centre workers have access to over 300 scripts from which to guide members through problems and to a data base on union member details. Unison members have made extensive use of the system, with 150,000 calls anticipated for 2001. The Transport and General Workers Union has developed an analogous facility for its members. These systems rely on call centres because half of union members are not yet on line and because many members may prefer information from a live person, but cost considerations will undoubtedly move them to the Web over time.

In the US the National Writers Union (www.nwu.org) has organized some 7,000 free lance writer members. The writers are spread out around the country and world, so the union almost has to deliver services via the Internet to them. The NWU views it website as the "cyberspace 
equivalent of the union hall where members (and prospective members) can find the information they need and conduct union business." (Hartford, 2001). The NWU sends emails several times a month to the entire membership, conducts most union business online, and averaged some 125,000 page views a month in early 2001. It includes a national job hotline, which lists freelance writing projects that members can apply for. In 2001, the NWU won a Supreme Court case on copyrights of written material on the Web against the NY Times (Greenhouse, 2001).

A major question is whether unions will provide e-services to non-members as well as to members. While some members may complain about using dues to service non-members, unions need web sites accessible to non-members to demonstrate what a union can do and to attract them. If non-union members got better service from, say, an Internet recruitment site or a labor law or government site, they would be unlikely to want to join the union.

Unions have adopted two strategies here. Many unions offer most information freely to persons who come to their web site, but have some restricted members' areas. As unions build up databases on members' preferences, problems, skills, etc, they will be able to differentiate the eservices to members and non-members more sharply. Only members will receive the customized service. The other strategy is to invest in web-sites designed specifically for non-members. Here, again, UNISON has been in the forefront of innovating. In 2000 it initiated www.troubleatwork.org.uk in conjunction with the National Union of Students, a site dedicated to providing information and advice on work-related problems for student workers. The topics covered range from health and safety issues to contracts to holidays, time out breaks, discrimination, lifting heavy objects, temping, to joining a union. 
The opportunity to customize services to members through the Internet and related computerbased technology is fundamental toward unions "re-inventing" themselves, and bridging the gap between individualistic workers and collective voice and action.

\section{H2: The Cyber-organizing hypothesis that the Web will create new modes of organizing and virtual union locals}

Organizing workers is the sine qua non task for American and British unions. In the US unions struggle to contact workers at the workplace, and the union organization historically disappear from a worksite in the wake of a defeat in an NLRB election. In the UK, unions have problems enrolling members even at work sites with a recognized union and a neutral or friendly management. How might the Internet help unions overcome problems in organizing?

The first thing the Web does is to make it easier for unions to present their case to workers and reach them outside of the firm. Employees can read information about the union without fear of reprisal from management, and they can do so at any time day or night. Once a union has the email addresses of potential members, it can contact them easily, customize the union appeal to them, and respond rapidly to company captive audience speeches and other communications. Already many unions have membership forms downloadable from their web site and some sign up members on-line.

US unions have been in the forefront of using the web for organizing. The United Food and Commercial Workers developed the site Www.walmartworkerslv.com to convince Wal-Mart 
workers to organize. The UFCW describes its Wal-Mart activity: "Although we do print publications as well, we've found most of our members use the Internet and enjoy this medium. They have learned about the process and keep up-to-date on current Wal-Mart activities online. It's also a vehicle for the community to see how our campaign is running and what we're really up against so that Wal-Mart Corporate is not the only one talking." The Service International Employees' Union used daily email messages and a chat room in its effort to organize nurses in Houston in 2000. The National Writers Union reports that $1 / 3$ rd to $1 / 2$ of its new members join via the Web. ${ }^{10}$

Second, and potentially more revolutionary, the Internet creates space for virtual unions -minority unions that exist on the Web but lack company recognition -- to become permanent fixtures in companies where unions cannot gain majority status or recognition. What is needed for a virtual union are a set of activists committed to developing a web site with information about issues in the company. With current technology, setting up a site can be done cheaply. The national union can provide some content, the site can sign up for free daily labour news (for instance from Labourstart.org) and for free business news about the firm; and it can post information from workers in the firm. All that is needed are a group of committed volunteer workers to maintain and update the site.

The archetype union of this type is www.allianceibm.org, associated with the Communication

\footnotetext{
${ }^{10}$ The effort to organize programmers at the French firm Ubi Soft through the Internet, however, failed (see www.mulimanialcom/ubifree/)
} 
Workers of America (CWA). Alliance@IBM comes from two groups www.ibmemployee.com and www.casepensions.org that formed in response to IBM's 1999 unilateral change in the company pension system which greatly harmed some future retirees. The workers protested in chat rooms and sounding boards around the Web, impelling IBM to restore some of the pension benefits. Alliance@IBM has a small number of voting members (75\% of whom signed up on line), a larger number of "subscribers" to email messages, and an even larger number of visitors, which undoubtedly includes managers. The alliance site provides discussion groups; mailing lists; links to related sites; and information about company issues of concern to workers. It was developed in large part by local members, making it a "grassroots" site (Guyer, 2001).

WashTech (www.washtech.org)_also associated with the CWA, is another virtual union, which represents the interest of Silicon Valley and related high tech industry workers. This organization raised the issue of overtime pay for contract employees at Microsoft and other high tech firms that hire many software engineers as contractors.

Even if workers at IBM, Microsoft and most other high tech firms never win an NLRB election, these sites make the union a part of the company in a way that was impossible prior to the Internet. Minority unions can be permanent fixtures in Cyber-space at any major company where some workers want some independent worker voice. 


\section{H3: The New Union Democracy hypothesis that the Web will make unions more member-driven}

The Internet can improve union democracy and accountability to members in ways that break Michel's "iron law of oligarchy" on the organization of unions. The information provided on the Web gives all members, rather than the few who attend a union meeting, access to information on policies and the opportunity to communicate views about those policies. This should encourage leaders to consult more with members before making key decisions (or suffer the consequences). In November 2000, the UK's MSF union canvassed members on its proposed merger with AEEU via ERBS web site. While dissidents rejected the legitimacy of the poll, the idea of using the Internet to learn how members think about an issue is valuable. Since the Web makes balloting cheap, moreover, turnout on strike votes, acceptance of contracts, and the like, ${ }^{11}$ should increase. In March 2000 the Society of Professional Engineering Employees (US) voted on their latest contract and to call off a strike on-line at Boeing. SPEEA members who were out of state could vote via the web, but the vast majority voted by normal means. In November 2000, the UK's CWU held an Internet ballot over accepting a collective bargaining. Turnout was $71.9 \%$.

The Internet can also increase union democracy by enhancing the ability of dissident groups to make their case to members. Union leaders may be leery of discussion boards that provide a platform for dissent, but dissident factions can develop their own sites to publicize their cause.

\footnotetext{
${ }^{11}$ In the UK the law requiring postal ballots on strikes will have to be amended to allow for Internet ballots on strike issues. The US has no legal barriers to Internet balloting on strikes or any other union business.
} 
Examples here include Teamsters for a Democratic Union, which uses the Web to convey information and which has organized campaigns on the Web for candidates for union office independent of the dominant union group (www.igc.org/tdu; www.leedham.org) In the UK Rogerlyons.com is devoted to criticizing the General Secretary of the MSF union Roger Lyons' expenditure of union money to defend himself against charges of financial indiscretion. As of March 2001, it had received over 12,000 hits and achieved notoriety throughout the union (www.davidbeaumont.btinternet.co.uk) .

Finally, the Web creates the potential for on-line union conferences and congresses. In Australia the ACTU, together 7 other unions, held a Unions Online Conference in November 1999. In May 2001 the Norwegian Confederation of Trade Unions - LO - set up a special web site (www.kongressen.no) to make available documents and resolutions, and broadcast the proceedings live in addition to web-TV interviews and chat sessions.

\section{H4. The Cyber-dispute hypothesis that the Web will alter industrial disputes.}

"There is no reason why thousands of workers could not simultaneously shut down their computers, just as strikers shut down assembly lines. Hackers have shown how defenseless businesses are to "denial of service" attacks - that is, to preventing employers from delivering services to the public by overloading their computers with requests for services ... collective cyber disruption is (workers') main source of power in dealing with capital in the new age, and they will invent the cyber equivalents of 
industrial sabotage, of working-to-rule, and of strikes." (Piven and Cloward)

Labor disputes have moved to the Web. The first and most common mode of using the Internet in disputes is union provision of on-line information about disputes. The Web allows unions to supplement or correct highly filtered media reporting at low cost and to inform members or the public about bargaining issues. The US Teamster's Union has made extensive use of the Internet to publicize its disputes with employers. In its 2000 dispute with Overnite, the Teamsters put up daily updates and sent out 4000 email alerts, some to customers of the firm. Teamster spokesman David Cameron, declared "The Internet has been phenomenal, clearly it's a means of communicating almost instantly with a wide variety of folks" (Dresang). Similarly, the Teamsters used the Internet to connect to members and the public in their successful 1997 strike against UPS. ${ }^{12}$ In the 2000 US Communication Workers strike against Verizon, the union posted daily bargaining updates on its web site with access restricted to members. In 1996 an Israeli academic union established an e-mail discussion forum for members and negotiators during a protracted labor dispute. The email forum closed the communication gap between negotiators and members and increased the unity and cohesion of the virtual community of strikers (Pliskin, Romm et al. 1997). ${ }^{13}$ Greer (2001) gives two striking examples where unions at Boeing made the Internet an integral part of strike management and bargaining sessions: the Seattle Professional Engineering Employees Association (www.speea.org) strike against the plane manufacturer in 2000 , where the union posted its detailed proposals regularly on the union

${ }^{12}$ The strike site http://www.teamster.org/ups.html is no longer operating.

${ }^{13}$ The UK site www.e-collectivism.org.uk provides links to several campaigns that use the web as part of their overall strategy. 
web site, with hits during the strike being "off the chart"; and the 2001 negotiations between the Southern California Professional Engineers Association (www.scpea.org) and the company, where the union provided daily accounts of bargaining and had an email link for members to give input to the negotiations committee.

Going further, some unions have used the Internet to organize wider protests to help workers in disputes in particular localities. In the Steelworkers strike in North Carolina against Germanowned Continental General Tire in 2000, the union provided information to activists around the US via Internet posting that led activists to pressure tire distributors and purchasers of Continental products including Walmart and Ford. Some 80-100 Internet postcards were sent to the headquarters in Germany. Changing the locus of the dispute from one of the least union friendly states in the US to the wider world helped the union win its dispute.

The third way labor disputes are coming to Cyberspace comes closer to the Piven and Clower modes of confrontation. The importance of company web sites informing customers about products even when most sales are off-line has made them a potential target for protests. Unions can organize "cyber picketing"14 - e-mail protests that flood a company's mail system or overload the company's web site with excessive requests for services During the winter 2000 Boeing strike in the US, activists listed the names of strikebreakers on web sites (Fioriti and Bass). But the most conflictual activities come from non-union protest groups. The Electronic

14“"Cyber-picketing is just a highfalutin' word for sending out thousands and thousands of e-mails and annoying the hell out of people annoying the hell out of people" (D. Cockroft, Teamsters in describing his union's tactics) 
Civil Disobedience web site (www.ecd.org) offers information on "hacktivisim" and related

Web-based tactics of disrupting normal communication on the Web. Prominent examples are the June 2000 takeover of www.nike.com, which directed people to a site that protested sweatshops and globalization; and the February 2001 hacking of the World Economic Forum site that obtained the credit cards of many of the rich and powerful.

\section{H5. The 'New Internationalism' hypothesis that the Web will strengthen the international labor community.}

"Thanks to the Internet, a century-long decline in internationalism has already been reversed. For thousands of trade unionists who log on every day, the International has already been born ... Union members, wherever they are located, can now facilitate workers' activities, organise discussion and formulate international policies in a way not possible before (Lee, 1998; 1997)

In books and articles Eric Lee of www.labourstart.org has presented the "new internationalism" hypothesis. The first component of new internationalism is the ready provision of up-to-date information on labor issues around the world. The two leading sources are Lee's www.labourstart.org and Steve Davies' www.cyberpicketline.org. Begun in March 1998, Labourstart provides daily labor news from newspapers around the world, which some 142 volunteer correspondents send to the site. It has over 100,000 unique visitors a month, discussion forums. Over 250 labour union sites run its daily free news service. The Cyberpicketline provides a directory of union web sites and information on disputes. Other sites 
provide information on labor conditions in less developed countries, focused on particular companies (vide Nike), countries (Indonesia, China, Central America), or groups or disputes. ${ }^{15}$

Going beyond provision of news and site information, LaborNet (US, www.labornet.org) and LabourNet (UK, www.labournet.net/world.asp\#ID) promote computer communications for strengthening and building organised labour. LabourNet states that because "International cooperation and solidarity has become totally essential." for unions to do their job. “... we are working towards the widest possible international labour network ... the fullest possible discussion on the issues facing our movement within LabourNet conferences, lists and our web sites for coming labour movement events, etc. from around the world. Our emphasis is on contributions and reports from rank and file trade unionists...."

International trade union secretariats have also shown a burst of new activity in Cyberspace. The ICFTU gives daily information releases via the Internet. The ICEM has established global networks at Goodyear, Rio Tinto, and Bridgestone. UNI has developed a web-site that provides detailed information about e-commerce and retail trade activities of companies and unions. The ITA international secretariat has worked to bring together the unions that represent airline workers at the various global alliances.

Publicizing labour disputes in foreign countries has limited the ability of some governments to suppress union activities. In 1999, the government of Korea arrested Korean Confederation of

${ }^{15}$ See Elliot and Freeman (2000) for a summary of some of these web sites and groups. 
Trade Union (KCTU) leaders. The KCTU sent out an urgent appeal by email to all its contacts in the international labour movement. The appeal was published on the LabourStart website and sent to the more than 1,400 subscribers to LabourStart's mailing list. The KCTU attributed the ensuing release of all the jailed trade unionists to the Internet based protest (Lee, 2000b) But international support for Liverpool dockers in the mid and late 1990s, some coordinated over the Web, did not produce victory for the dockers (www.labournet.net/docks2/other/topdock.htm).

\section{Competition in cyberspace}

Unions are not the only organization delivering services to workers over the Internet. Look for career advice, jobs, salaries, job training, or legal employment problems, on any search engine and a host of commercial and other non-union sites will pop up. Whether unions will prosper in cyberspace depends in part on how they meet the competition.

Internet recruitment sites are the most noticeable competitors - one of the commercial successes on the Web (Diamond and Freeman, 2001). The sites gain revenue from employers who pay for listing job vacancies or for the right to search CV databases, but to succeed the site must attract workers. To do this, they provide free services to workers along with the opportunity to find a job from the listed vacancies. Most internet recruitment sites offer: email notification of job openings; career advice and information; salary surveys; advice on job search and preparing a $\mathrm{CV}$; on-line job applications. Many conduct on-line surveys; provide FAQ information on legal employment issues as well as more mundane matters; and give news about the occupation or industry where someone is seeking work. Some provide email questions and answers on work 
related issues; email career newsletters; and have chat rooms for job applicants. Some offer links to training sites and provide on-line personality tests.

The most progressive sites seek to become personal agents for workers: "a complete employment network, connecting people who want to change the way they work, develop their careers, update their skills and find new jobs, with the employers, businesses and professionals who want to reach them" (www.workthing.com.uk) One major UK recruitment firm said that its goal was to recommend training to persons whose $\mathrm{CV}$ does not attract much employer interest, get them a new job at a new location, and then recommend realtors and movers, tailors, restaurants, etc. Its profit would come from earning commissions from all the businesses to whom it had steered the job applicant. If these firms succeed, the space for unions to represent workers will narrow considerably.

Other Internet sites also offer services to workers. Labor law firms offer free leg al advice (www.electoniclaw.uk, www.lawrights.co.uk; . www.employment-solicitors.co.uk;

www.emplaw.co.uk;). Government agencies provide diverse work related information (www.dol.gov/elaws). Professional associations offer services (www.programmersguild.org). There are general sites that have discussions or forums on employment issues (http://ivy.ivillage.co.uk) and specialized sites that deal with the employment problems of particular groups, such as lesbians and gays (www.lager.dircon.co.uk). And there on-line training sites offering training in virtually anything.

The BWRPS asked workers with Web access the kinds of employment-related information or 
communication they would find useful from a website. Exhibit 5 shows that union and nonunion members found most of the suggested services very or somewhat useful, with union members being somewhat more positive about all but one service than non-union members. The exception is information about salaries for people in their line of work. In union settings, salary information is more openly available due to collective bargaining than in non-union settings. ${ }^{16}$

Unions have some advantages in competing with these other organizations to represent workers in Cyberspace. Unions have experience in protecting labor workers. If management treats workers poorly, a union can organize collective action or use its political power to attract government or media attention. Workers are more likely to believe that elected union representatives will put their interests first than will recruitment agencies paid by employers.

Unions have one major disadvantage in attracting workers to their site. They are not a natural source of job vacancies. If you want a new job, you are likely to click on Monster.com not AFLCIO.org. This is important because job search is one of the most common uses of the Web. One way for unions to remedy this problem is to post vacancies on their sites, as the Teamsters and Communication Workers in the US do, or to develop their own recruitment consultancy as Connect in the UK does (www.opus2jobs.com). Another way to deal with the problem is for the union to develop strategic partnerships with recruitment commercial firms. The union would

${ }^{16}$ Paul Evans of Poptel has conducted a survey (non-random sample) of union internet users that gives a similar picture. His sample consists largely of union officials, unpaid as well as paid. The major areas that they see as useful for their union website are consultation and communication, offering information and advice to members. The use they favored least was online voting about union-related matters. 
trade access to its members and other users of its site for commercial content that the firms would use to gain them job applicants. Conversely, workers seeking jobs or training or legal advice at the commercial sites would be directed to the relevant union. Unions might even assist organized firms in recruiting by offering on-line applicants access to union chat rooms or information. The Spanish Internet recruitment site, www.canalrabajo.com contains a direct link to the Spanish trade unions.

To see how well extant union web sites were doing in the UK in 2001, we asked union members with Internet access whether they had accessed their union's website and, if they had, to grade the site. The results, summarized in exhibit 6 , show that UK unions have a long way to go to make their web sites relevant to most members. Just twenty-percent of members with Internet access have ever visited their unions' web site, and of those that did as many put the site in the poor or failure category as gave it an excellent rating. That $22 \%$ of union members didn't know whether their union had a web site shows that while some unions and some activists are attuned to using the new technology, many unions and members that have yet to move seriously into Cyberspace.

\section{Conclusion: Toward the E-Union?}

If our five hypotheses prove correct, within the next decade unions in the UK and US will change many of the services they provide members and the ways in which they operate, potentially morphing into a new "E-union" organizational form that will differ as much from current union 
organizations as industrial unions differed from their craft union predecessors. Exhibit 7 shows how we envisage a $21^{\text {st }}$ Century E-union would differ from traditional $20^{\text {th }}$ Century unions. We expect unions to provide individual representation and customized services as well as collective bargaining; to deliver services on the Web as well as at workplaces, to use digital technology, including AI expert systems to respond to members' problems; and to offer more services outside of collective bargaining. Union membership will become fuzzier, ranging from dues-paying members at recognized sites to near-members or subscribers at virtual union sites. Unions will deal with free rider problems by customizing services to members only and will operate in a more decentralized member-driven manner.

Our evidence shows that one and usually more unions or union activists use the Web in some of the ways given above but that no single union has put all the pieces together to create the "eunion" of the future, and that many unions fall far short of modernizing their practices. That all the pieces for a new union movement can be found in different places does not, of course, mean that unions will successfully put them together to revive the union movement in the near future. ${ }^{17}$ There is, as noted, competition in cyberspace for providing services to workers. There are potential legal problems in workers using the Internet at their workplace to contact unions and in

17 Some British unions have given considerable thought to putting the pieces together. The Engineering and Management Association (EMA) union has developed a business plan for an e-union,4U@work, that would offer legal advice, access to union expertise, assistance in workplace disputes, and other services through the Internet, some free and some available only for a fee. The TUC's Task Group on Promoting Trade Unionism has explored developing eunion services to non-union workers, to change the image of the union movement and to show these workers the benefits of unionization. 
unions using the firms intranet or the Internet to connect with members. ${ }^{18}$ And there are organizational problems in moving large democratic organizations, usually run by pre-Internet leaders, to pursue the opportunities that the Internet offers, particularly when some Internet activities are likely to change the organization's power structure. ${ }^{19}$

But the pressure on unions to use the Internet to improve their services and modes of operating is a powerful one. Natural selection will weed out unions that fail to exploit the Internet while those that find the right mix of services and activities on the Web will grow. Unions will copy what works best and spread best practice. The lesson of the business side of the Internet that success is more likely to come to firms with strong brands and products in the normal commercial world than to Internet start-ups bodes well for union Internet activities. Still, success in cyberspace does not guarantee a renaissance of unionism. It is one part of the process of unions' adapting to new economic circumstances and the changing concerns of workers and firms - a necessary but not sufficient condition for unions to prosper in the $21^{\text {st }}$ Century..

18 The UNI international trade union secretariat has taken a lead in examining issues regarding union members use of the Internet at work. UNI has a model agreement on issues of electronic surveillance and personal privacy. .

19 The problem has been stated succinctly by Paul Mason, "the more bureaucratic organizations are, the less effectively they use the Web; the more an organization's members use the Web, the more bureaucracy is undermined". 


\section{References}

Bibby, Andrew “On-Line Rights for On-Line Workers”, presented at TUC-LSE-Harvard TUP Conference Unions and the Internet, May 21-22,2001

Bimber, Bruce "The Internet and Political Transformation: Populism, Community, and Accelerated Pluralism" Polity 1998 (Vol XXXI, number 1, pp 133-160.

Castells Manuel 1997 The Information Age. Vol II The Power of Identity. Oxford, Blackwell.

Corrado, Anthony and Charles Firestone (eds) Elections in Cyberspace (Washington DC, Aspen Institute 1996)

Darlington, Roger "The creation of the E-Union: the use of ICT by British unions" given at Internet Economy Conference at the Centre for Economic Performance, London School of Economics on 7 November 2000, http://members.tripod.co.uk/rogerdarlington/E-union.html

Diamond Wayne and Richard Freeman, "Job Search and Recruitment in Cyberspace" seminar presentation LSE, October 19, 2000

Diamond Wayne and Richard Freeman "What workers want from Workplace organizations" mimeo August 9, 2001 
Dresang, Joel "Unions take picket lines online" www.nandotimes.com, November 8, 1999 $11 / 1 / 99$

Evans, Paul, "Trade Unionists and their use of the Internet", www.poptel.net/survey/reports/SurveyReport.asp?s=178, downloaded 11/05/01

Fioriti, Jack and William Bass "Information Technology Use in National Unions: An Exploration (Industrial Relations, 2000).

Greer, Charles "E-Voice: How Information Technology is Shaping Life Within Unions" (Texas Christian University, May 17, 2001)

Grossman, Lawrence, The Electronic Republic: Reshaping Democracy in America (New York, Viking, 1995)

Guyer, Linda "WWW.allianceibm.org" real world experiences of online organizing presented at Unions and the Internet Conference, London, May 21-22, 2001

Hartford, Bruce "Riding the Internet" presented at Unions and the Internet Conference, London, May 21-22, 2001 
Hodkinson, Stuart "Reviving Trade Unionism: Globalisation, Internationalism, \& the Internet" paper delivered Grenoble France, European Consortium for Political Research meetings April 2001

Industrial Relations Services, Employment Trends (Eclipse Group, London, UK)

Lee, Eric The Internet belongs to everyone: Radical thoughts on the governance of cyberspace(Summer 2000; http://www.labourstart.org.uk/icann/)

Lee, Eric, "Beyond the website: The experience of LabourStart's labour newswire, in The CyberUnion Handbook: Transforming Labor through Computer Technology, edited by Art Shostak M.E.Sharpe, 2001.

Lee, Eric, “The Labour Movement and the Internet: The New Internationalism” (Pluto Press, 1996).

Lee, Eric, "Korean unions: Internet-based solidarity freed our leaders from jail”. Published in Action for Solidarity (UK), 13 January 2000

Mason, Paul, "ReedNUJ.org: How Workplace Activists used the Internet in a white-collar union recognition campaign” Unions and the Internet Conference, London, May 21-22, 2001

Needham, Catherine, "Electronic Communication in the UK and US” April 2001, Grenoble. 
France, European Consortium for Political Research meetings

Negroponte, Nicholas Being Digital NY Vintage 1995

Piven Francis and Richard Cloward "Labour Power in Cyberspace" mimeo working paper, New York, August 2000 www.

Pliskin, Nava.Celia T. Romm, and Raymond Markeyl (1997) "E-mail as a weapon in an industrial dispute” New Technology, Work and Employment vol 12, issue 1, 3-12.

Shostak, Arthur, “ CyberUnion: Empowering Labor Through Computer Technology,1999, M. E. Sharpe, Inc.

Shostak, Arthur "Organizing via CyberUnions: Can $21^{\text {st }}$ Century CyberUnions be Created in time?"www.cyberunions.net/articles/orgviacu.html

Theier, Adam "How Free Computers are Filling the Digital Divide” Heritage Foundation Backgrounder Executive Summary, April 20, 2000 no 1361.

UNI, Union Network International “On-line rights for on-line workers, Model Electronic Facilities Agreement" mimeo, 26/04/2001 www.union-network.org/UNIsite/ 
Exhibit 1: UK workers on the web

\begin{tabular}{|c|c|c|}
\hline & \multicolumn{2}{|c|}{ Union Membership Status } \\
\hline & Member & Non-Member \\
\hline Have you used the internet in the last month? & $50.2 \%$ & $45.5 \%$ \\
\hline From home (or via domestic technology) & $78.6 \%$ & $81.6 \%$ \\
\hline At home on computer & $77.4 \%$ & $77.9 \%$ \\
\hline At home on game console & $0.9 \%$ & $1.7 \%$ \\
\hline Through digital cable TV & $1.3 \%$ & $3.0 \%$ \\
\hline Through ONDigital TV & $0.4 \%$ & $0.7 \%$ \\
\hline Through TV set top box & $0.4 \%$ & $5.0 \%$ \\
\hline At work & $49.1 \%$ & $44.3 \%$ \\
\hline From public access machines (cafe, library, school, etc) & $9.0 \%$ & $14.9 \%$ \\
\hline At school / university & $7.7 \%$ & $11.7 \%$ \\
\hline In a cafe, bar or library & $1.3 \%$ & $3.7 \%$ \\
\hline Internet Kiosk & - & $0.7 \%$ \\
\hline From a mobile platform & $1.3 \%$ & $4.2 \%$ \\
\hline On a mobile phone & $1.3 \%$ & $4.0 \%$ \\
\hline On palmtop/(PDA) & - & $1.0 \%$ \\
\hline Friend's/relatives house & $4.3 \%$ & $5.0 \%$ \\
\hline Other & - & $0.2 \%$ \\
\hline
\end{tabular}

Source: BWRPS (2001); Q65 "Where have you accessed the internet from?" 
Exhibit 2: Use of Internet for E-Union type activities in last 6 months

\begin{tabular}{lcc}
\hline & Member & Non-Member \\
\cline { 2 - 3 } & & \\
Taking part in discussions or online chat & $19.2 \%$ & $22.8 \%$ \\
To look at job opportunities & $29.1 \%$ & $41.9 \%$ \\
Accessing bulletin boards or newsgroups & $22.2 \%$ & $25.6 \%$ \\
Finding information about financial investments or share prices & $19.2 \%$ & $24.8 \%$ \\
Finding information about your legal rights & $6.8 \%$ & $10.7 \%$ \\
& & \\
Any of the Above Activities & $59.8 \%$ & $63.8 \%$ \\
\end{tabular}

Source: BWRPS (2001); Q67 "Which of the following activities have you used the Internet for in the last 6 months?" 
Exhibit 3: Use of the Internet by US Workers

\begin{tabular}{|c|c|c|}
\hline & \multicolumn{2}{|c|}{$\begin{array}{c}\text { Union } \\
\text { Membership Status }\end{array}$} \\
\hline & Union & Non-Union \\
\hline Do you regularly use the internet from home? & $79.4 \%$ & $86.0 \%$ \\
\hline \multicolumn{3}{|l|}{ Regular use of internet from home for... } \\
\hline Checking news, weather, or sports & $43.2 \%$ & $45.6 \%$ \\
\hline Searching for information & $51.8 \%$ & $56.2 \%$ \\
\hline Searching for jobs & $11.1 \%$ & $18.7 \%$ \\
\hline Job-related tasks & $28.1 \%$ & $31.1 \%$ \\
\hline Shopping, paying bills, or other commercial activities & $32.5 \%$ & $34.4 \%$ \\
\hline \multicolumn{3}{|l|}{ Internet use outside the home for... } \\
\hline Checking news, weather, or sports & $21.4 \%$ & $23.5 \%$ \\
\hline Searching for information & $50.1 \%$ & $48.0 \%$ \\
\hline Searching for jobs & $7.8 \%$ & $8.7 \%$ \\
\hline Job-related tasks & $60.3 \%$ & $62.5 \%$ \\
\hline Shopping, paying bills, or other commercial activities & $7.4 \%$ & $11.4 \%$ \\
\hline \multicolumn{3}{|l|}{ How do you access the internet at home? } \\
\hline Regular, or dial-up telephone service & $92.0 \%$ & $89.5 \%$ \\
\hline Higher-speed Internet access service & $8.0 \%$ & $10.5 \%$ \\
\hline
\end{tabular}

Source: CPS Internet and Computer Use Supplement (August 2000) PEERNLAB "On this job are you a member of a labour organisation or of an employees organisation similar to a union?" PRS11 "Internet use at home for any purpose" PES11x "Does [respondent] regularly use the internet [at home] for..." PES17x "Does [respondent] use internet outside the home for..." 
Exhibit 4: Centre for Economic Performance Listing of Union Web Sites by Country and type of Organisation, as of April 2001

\begin{tabular}{|c|c|c|c|c|c|}
\hline Country & $\begin{array}{l}\text { Main } \\
\text { Union }\end{array}$ & $\begin{array}{c}\text { Local Union } \\
\text { Branches }\end{array}$ & $\begin{array}{c}\text { Regional } \\
\text { Union Sites }\end{array}$ & $\begin{array}{c}\text { National } \\
\text { Federations }\end{array}$ & Total \\
\hline United Kingdom & 75 & 278 & 13 & 7 & 373 \\
\hline USA & 116 & 557 & 18 & 2 & 693 \\
\hline OECD - Other English Speaking & 142 & 289 & 24 & 6 & 461 \\
\hline OECD - Non-English Speaking & 610 & 144 & 51 & 72 & 856 \\
\hline Non-OECD & 161 & 31 & - & 45 & 242 \\
\hline International Organisations & - & - & - & - & 60 \\
\hline Albania & & & & 1 & 1 \\
\hline Australia & 46 & 99 & 6 & 1 & 152 \\
\hline Austria & 16 & 1 & 4 & 1 & 22 \\
\hline Azerbaijan & 1 & & & & 1 \\
\hline Bahamas & 1 & & & & 1 \\
\hline Barbados & 3 & & & & 3 \\
\hline Belarus & 1 & & & 1 & 2 \\
\hline Belgium & 13 & & 5 & 2 & 20 \\
\hline Brazil & 51 & 30 & & 3 & 84 \\
\hline Bulgaria & & & & 1 & 1 \\
\hline Canada & 82 & 190 & 17 & 4 & 293 \\
\hline Cape Verde & 1 & & & & 1 \\
\hline Chile & 3 & & & & 3 \\
\hline China & 3 & & & 2 & 5 \\
\hline Costa Rica & 1 & & & & 1 \\
\hline Croatia & 3 & & & & 3 \\
\hline Cyprus & 4 & & & 2 & 6 \\
\hline Czech Republic & 13 & & & 1 & 14 \\
\hline Denmark & 45 & & & 3 & 48 \\
\hline Dominica & 1 & & & & 1 \\
\hline El Salvador & 1 & & & & 1 \\
\hline Estonia & & & & 1 & 1 \\
\hline Finland & 25 & & & 3 & 28 \\
\hline France & 149 & 27 & & 5 & 181 \\
\hline Germany & 27 & 24 & 4 & 4 & 59 \\
\hline Grenada & & & & 1 & 1 \\
\hline Hungary & 7 & & & 3 & 10 \\
\hline Iceland & 9 & & & 1 & 10 \\
\hline India & 7 & & & 4 & 11 \\
\hline Indonesia & & & & 1 & 1 \\
\hline International & & & & & 60 \\
\hline Ireland & 14 & & 1 & 1 & 16 \\
\hline Israel & 3 & & & & 3 \\
\hline
\end{tabular}

(Cont'd overleaf) 


\begin{tabular}{|c|c|c|c|c|c|}
\hline Country (Cont'd) & $\begin{array}{l}\text { Main } \\
\text { Union }\end{array}$ & $\begin{array}{c}\text { Local Union } \\
\text { Branches }\end{array}$ & $\begin{array}{c}\text { Regional } \\
\text { Union Sites }\end{array}$ & $\begin{array}{c}\text { National } \\
\text { Federations }\end{array}$ & Total \\
\hline Italy & 43 & 36 & 31 & 3 & 113 \\
\hline Jamaica & 2 & & & 1 & 3 \\
\hline Japan & 29 & & & 4 & 33 \\
\hline Kazakhstan & & & & 1 & 1 \\
\hline Lithuania & 1 & & & 1 & 2 \\
\hline Luxembourg & 8 & & & 2 & 10 \\
\hline Malaysia & 3 & & & 1 & 4 \\
\hline Malta & 3 & & & & 3 \\
\hline Mauritius & 1 & & & & 1 \\
\hline Mexico & 6 & 1 & & & 7 \\
\hline Nepal & & & & 2 & 2 \\
\hline Netherlands & 35 & & & 6 & 41 \\
\hline New Zealand & 11 & & & 2 & 13 \\
\hline Norway & 40 & 42 & 4 & 7 & 93 \\
\hline Palestine & & & & 1 & 1 \\
\hline Philippines & 3 & & & 3 & 6 \\
\hline Poland & 4 & & & 4 & 8 \\
\hline Portugal & 21 & & & 4 & 25 \\
\hline Puerto Rica & 1 & & & & 1 \\
\hline Romania & 2 & & & 3 & 5 \\
\hline Russia & 2 & & & 4 & 6 \\
\hline San Marino & & & & 2 & 2 \\
\hline Singapore & 1 & & & 1 & 2 \\
\hline Slovakia & 4 & & & 1 & 5 \\
\hline Slovenia & 5 & & & 1 & 6 \\
\hline South Africa & 14 & & & 2 & 16 \\
\hline South Korea & 16 & & 3 & 2 & 21 \\
\hline Spain & 32 & 3 & & 5 & 40 \\
\hline St Lucia & 1 & & & & 1 \\
\hline Swaziland & & & & 1 & 1 \\
\hline Sweden & 39 & 7 & & 7 & 53 \\
\hline Switzerland & 17 & & & 2 & 19 \\
\hline Taiwan & 2 & & & 1 & 3 \\
\hline Trinidad and Tobago & 3 & 1 & & & 4 \\
\hline Tunisia & 1 & & & & 1 \\
\hline Turkey & 10 & 3 & & 1 & 14 \\
\hline Ukraine & 1 & & & & 1 \\
\hline Uruguay & 4 & & & & 4 \\
\hline Venezuela & 1 & & & & 1 \\
\hline Yugoslavia & 1 & & & 1 & 2 \\
\hline Zimbabwe & & & & 1 & 1 \\
\hline Total & 1088 & 1299 & 106 & 132 & 2685 \\
\hline
\end{tabular}

Source: CEP Survey of Union Websites (April 2001) 
Exhibit 5: How useful would you personally find each of the following services if provided on a website?

\begin{tabular}{|c|c|c|c|c|c|}
\hline & $\begin{array}{c}\text { Very } \\
\text { useful }\end{array}$ & $\begin{array}{l}\text { Quite } \\
\text { useful }\end{array}$ & $\begin{array}{c}\text { Not very } \\
\text { useful }\end{array}$ & $\begin{array}{c}\text { Not at all } \\
\text { useful }\end{array}$ & $\begin{array}{l}\text { Don't } \\
\text { Know }\end{array}$ \\
\hline \multicolumn{6}{|l|}{$\begin{array}{l}\text { Information and reviews about your employer or } \\
\text { another employer that you might consider working for }\end{array}$} \\
\hline Member & $34.2 \%$ & $46.2 \%$ & $11.5 \%$ & $4.3 \%$ & $3.8 \%$ \\
\hline Non-Member & $37.2 \%$ & $39.7 \%$ & $12.2 \%$ & $7.4 \%$ & $3.5 \%$ \\
\hline \multicolumn{6}{|l|}{ Advice about pensions and personal finance } \\
\hline Member & $35.9 \%$ & $39.3 \%$ & $13.2 \%$ & $6.8 \%$ & $4.7 \%$ \\
\hline Non-Member & $30.0 \%$ & $44.2 \%$ & $9.9 \%$ & $12.9 \%$ & $3.0 \%$ \\
\hline \multicolumn{6}{|l|}{$\begin{array}{l}\text { Information about salaries for people in your line of } \\
\text { work }\end{array}$} \\
\hline Member & $35.5 \%$ & $33.8 \%$ & $18.8 \%$ & $8.5 \%$ & $3.4 \%$ \\
\hline Non-Member & $35.5 \%$ & $40.0 \%$ & $12.2 \%$ & $9.7 \%$ & $2.7 \%$ \\
\hline \multicolumn{6}{|l|}{$\begin{array}{l}\text { Discussion forums for people at your workplace or } \\
\text { people doing your type of job in another workplace }\end{array}$} \\
\hline Member & $25.6 \%$ & $41.5 \%$ & $19.7 \%$ & $9.4 \%$ & $3.8 \%$ \\
\hline Non-Member & $21.6 \%$ & $39.7 \%$ & $22.8 \%$ & $12.7 \%$ & $3.2 \%$ \\
\hline \multicolumn{6}{|l|}{ Advice about your rights at work } \\
\hline Member & $36.8 \%$ & $48.3 \%$ & $6.8 \%$ & $4.3 \%$ & $3.8 \%$ \\
\hline Non-Member & $39.0 \%$ & $39.5 \%$ & $9.4 \%$ & $8.4 \%$ & $3.7 \%$ \\
\hline
\end{tabular}

Source: BWRPS (2001); Q68 "some websites provide information and services to people at work. How useful would you personally find each of the following services if provided on a website?" 
Exhibit 6: Internet Active Union Members' knowledge and Assessment of their Union's Web Site

\begin{tabular}{lc}
\hline & $(\%)$ \\
\cline { 2 - 2 } $\begin{array}{l}\text { Internet Active Union Members who have ever visited } \\
\text { their own Union's web site }\end{array}$ & $19.7 \%$ \\
& Usefulness of union web site \\
Excellent & $14.3 \%$ \\
Good & $36.7 \%$ \\
Fair & $34.7 \%$ \\
Poor & $14.2 \%$ \\
Not visited own union web site & $52.1 \%$ \\
Union does not have a web site & $6.4 \%$ \\
Don't Know & $21.8 \%$ \\
All Union members who have ever visited their own & $9.9 \%$ \\
union's web site & \\
\hline
\end{tabular}

Source: BWRPS (2001). Q69 “To the best of your knowledge does your union have a website? If so, have you ever visited it?" Q70 “ How useful did you personally find your union web site?" 
Exhibit 7: The Transformation of Unions in the Internet Era

\begin{tabular}{|c|c|c|}
\hline & Pre-Internet Activities of Unions & Additional Activities After Internet \\
\hline Primary business & Collective Bargaining & Individual representation and advice \\
\hline \multirow[t]{3}{*}{ Delivery of services } & Workplaces & Web \\
\hline & Services delivered by reps/leaders & Digital AI services \\
\hline & $\begin{array}{l}\text { Outcomes depend on collective Bargain } \\
\text { with employer }\end{array}$ & Services provided directly to workers \\
\hline \multirow[t]{2}{*}{ Method of Dispute } & Strikes & $\begin{array}{l}\text { Web communication } \\
\text { Cyber picketing }\end{array}$ \\
\hline & Pre-Internet Membership & Post-Internet Membership \\
\hline Locale & $\begin{array}{l}\text { Workplace; } \\
\text { Members with employer recognition }\end{array}$ & $\begin{array}{l}\text { Differentiated membership: } \\
\text { - members, subscribers, } \\
\text { - visitors to website } \\
\text { - Virtual presence at workplaces }\end{array}$ \\
\hline Free rider problems & $\begin{array}{l}\text { Collective bargain creates incentive to } \\
\text { free ride }\end{array}$ & Customized services to members only \\
\hline Internal Democracy & Elected leaders and bureaucracy & $\begin{array}{l}\text { Decentralized; Internet plebiscites } \\
\text { Activists operate independently }\end{array}$ \\
\hline
\end{tabular}


Appendix A: Multivariate Logistic and Ordered Probit Analysis of UK Workers Use of the Internet

\begin{tabular}{|c|c|c|c|c|c|c|c|c|c|c|}
\hline & \multicolumn{3}{|c|}{$\begin{array}{c}\text { Internet Access in past } \\
\text { Month? } \\
(\mathrm{Y}=1)\end{array}$} & \multicolumn{3}{|c|}{$\begin{array}{c}\text { Internet Active Union } \\
\text { Member - ever visited } \\
\text { Union Website } \\
(\mathrm{Y}=1)\end{array}$} & \multicolumn{2}{|c|}{$\begin{array}{c}\text { Accessed Internet from } \\
\text { Home? } \\
(\mathrm{Y}=1)\end{array}$} & \multicolumn{2}{|c|}{$\begin{array}{l}\text { When First used the } \\
\text { Internet? } \\
\text { ( } 5 \text { bands) }\end{array}$} \\
\hline & $\mathrm{B}$ & & SE & $\mathrm{B}$ & & SE & $\mathrm{B}$ & SE & $\mathrm{B}$ & SE \\
\hline Union Membership (Member=1) & 0.13 & & 0.16 & - & & - & -0.44 & 0.28 & -0.18 & 0.11 \\
\hline Union at workplace $($ Yes $=1)$ & - & & - & -0.54 & & 0.79 & - & - & - & - \\
\hline Age & -0.06 & & 0.01 & -0.01 & & 0.02 & 0.04 & 0.01 & -0.01 & 0.00 \\
\hline Sex $($ Male $=1)$ & 0.23 & & 0.16 & 1.29 & & 0.46 & 0.76 & 0.26 & 0.19 & 0.10 \\
\hline Public vs. Private Sector (Public=1) & 0.23 & & 0.17 & 1.15 & & 0.51 & 0.30 & 0.29 & 0.32 & 0.12 \\
\hline Pay (mid-point in Pay Band) & 0.00 & & 0.00 & 0.00 & & 0.00 & 0.00 & 0.00 & 0.00 & 0.00 \\
\hline Top Pay Band (Dummy) & -1.13 & & 0.57 & - & & - & 1.97 & 1.16 & -0.03 & 0.32 \\
\hline Manager or Non-manager (Manager $=1$ ) & 0.40 & & 0.28 & -0.04 & & 0.69 & -0.38 & 0.41 & 0.23 & 0.17 \\
\hline Usual working hours per week & -0.02 & & 0.01 & 0.01 & & 0.02 & 0.00 & 0.01 & -0.01 & 0.00 \\
\hline \multicolumn{11}{|l|}{ Highest Qualification: } \\
\hline None (Reference) & - & & - & - & & - & - & - & - & - \\
\hline GCSE or Equivalent & 0.75 & & 0.24 & -0.42 & & 0.94 & -1.85 & 1.04 & -0.04 & 0.20 \\
\hline A-Level or Equivalent & 1.12 & & 0.26 & 0.15 & & 0.96 & -2.10 & 1.05 & 0.18 & 0.21 \\
\hline Degree or Equiv & 1.51 & & 0.28 & 1.04 & & 0.92 & -2.50 & 1.06 & 0.24 & 0.22 \\
\hline Postgraduate or Equiv. & 2.15 & & 0.42 & 1.12 & & 0.99 & -1.70 & 1.15 & 0.63 & 0.27 \\
\hline Other & 0.79 & & 0.36 & - & & - & -1.81 & 1.21 & -0.27 & 0.30 \\
\hline Constant & 0.48 & & 0.36 & -2.40 & & 1.58 & 2.25 & 1.11 & - & - \\
\hline \multicolumn{11}{|l|}{ First used the Internet } \\
\hline Less than six months ago [CUT 1] & & - & & - & - & - & 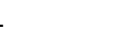 & & -1.18 & 0.27 \\
\hline Between six months and a year[CUT 2] & & - & & - & - & - & 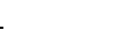 & & -0.77 & 0.27 \\
\hline 1 to 2 years ago [CUT 3] & & - & & - & - & - & - & & 0.01 & 0.27 \\
\hline 3 to 4 years ago [CUT 4 ] & & - & & - & - & - & - & & 0.63 & 0.27 \\
\hline More than 4 years ago [CUT 5] & & - & & - & - & - & - & & 1.09 & 0.27 \\
\hline Observations & 1089 & & & 194 & & & 511 & & 510 & \\
\hline Pseudo R-Squared & 0.18 & & & 0.12 & & & 0.08 & & 0.04 & \\
\hline
\end{tabular}

Source: BWRPS (2001) Q65 "Have you used the internet in the past month?" Q66 "When did you first use the internet?" Q69 "To the best of your knowledge does your union have a website? If so, have you ever visited it?" Columns 1 -3 are logistic models; column 4 is the ordered Probit model 